\title{
Anemia in antenatal patients and its outcome: an experience in tertiary care centre
}

\author{
Shabnam Ara*, Cimona Lyn Saldanha, Insha Khan
}

Department of Obstetrics and Gynecology, Sher-I-Kashmir of Medical Sciences, Srinagar, Jammu and Kashmir, India

Received: 01 June 2018

Accepted: 03 July 2018

\section{*Correspondence:}

Dr. Shabnam Ara,

E-mail: drkhan9678@gmail.com

Copyright: (C) the author(s), publisher and licensee Medip Academy. This is an open-access article distributed under the terms of the Creative Commons Attribution Non-Commercial License, which permits unrestricted non-commercial use, distribution, and reproduction in any medium, provided the original work is properly cited.

\begin{abstract}
Background: Anemia is the most common hematological abnormality detected during the pregnancy and forms a major problem in affecting the females especially in the developing countries.

Methods: All pregnant females with clinical evidence of anemia without any other co-morbidity attending the antenatal clinic were included in the study. Patients were studied in terms of the age, parity, inter-pregnancy spacing, type of pregnancy, post-partum outcome along with the biochemical tests like peripheral blood picture, hemoglobin estimation, and serum ferritin levels.

Results: Total no. of patients was 500 , age $\leq 20$ years were 60 and $\geq 35$ years were 107 , mild anemia $(10-10.9$ gm $\%)$ 160, moderate anemia (7-10 gm\%) 250, severe anemia ( $<7 \mathrm{gm} \%)$ 90. Normal vaginal delivery with medio-lateral episiotomy was done in 385 patients, normal vaginal delivery without medio-lateral episiotomy in 35 while lowersegment caesarean section in 80 patients. Pre-term delivery was done in 95 patients, post-term delivery in 20.90 babies delivered were low-birth weight $(<2500 \mathrm{gm})$, antepartum hemorrhage was seen in 10 patients while 20 patients had Post-partum hemorrhage.

Conclusions: The present study concludes that anemia is still rampant in the society especially in pregnant women. The main cause of anemia-in-pregnancy is still the iron deficiency anemia. The peripheral blood picture, hemoglobin estimation, and serum ferritin levels form the basic pillars in the evaluation of the etiology and type of anemia. The multiple government sponsored facilities are to be made available to each pregnant female and that requires community, government as well as healthcare professional's participation.
\end{abstract}

Keywords: Anemia, Antepartum, Low birthweight, Parity

\section{INTRODUCTION}

Anemia is the most common hematological abnormality detected during the pregnancy, most often due to iron deficiency and occasionally by more complex conditions involving decreased production and accelerated destruction of erythrocytes. Although anemia affects all the age-groups, but it is most common in pregnant women. ${ }^{1}$ Anemia forms a major problem affecting the females especially in the developing countries. Poor nutrition and increased demands are the main reasons of anemia in pregnancy. Thus, it can be prevented if females are educated about the values of proper nutrition and need of iron and folic acid supplementation during pregnancy. It is not only a major contributor to maternal morbidity and mortality but also affects the neonatal outcome to a greater extent. It can result in many comorbidities during the pregnancy like congestive heart failure, increased susceptibility to infections, preeclampsia, antepartum hemorrhage, sub-involution of uterus besides prematurity of the fetus and low-birth weight babies. ${ }^{2}$ 


\section{METHODS}

The present prospective observational study was conducted in the Department of Obstetrics and Gynecology of our institute and Sub-District Hospital Kangan between May 2016 and April 2017. All pregnant females with clinical evidence of anemia attending the antenatal clinic were included in the study. Only the cases without any co-morbidity were included in the study. The patients having any other associated morbidity like hypertension, diabetes, hypothyroidism, hepatic disorders, and bone marrow disorders were excluded from the study. The total of 500 patients were included in the final statistical analysis. After registration, data was collected in a pre-structured questionnaire.

Table 1: Classification of severity of anemia.

\begin{tabular}{|ll|}
\hline Hemoglobin level $(\mathrm{gm} \%)$ & Severity of anemia \\
\hline $10-10.9$ & Mild \\
\hline $7-10$ & Moderate \\
\hline$<7$ & Severe \\
\hline
\end{tabular}

A thorough physical examination was done in all patients. Hemoglobin estimation was done by automated hematology analyzer using colorimeter methods. The standard peripheral blood films of all these patients were analyzed to classify the anemia as hypochromic, normochromic or hyperchromic; and macrocytic and microcytic type. Anemia was defined and classified as mild, moderate, and severe as per WHO criteria (Table 1). In addition, serum ferritin levels of these patients were also measured.

Mild: 10-10.9 gm\%, moderate: 7-10 gm\% and severe: less than $7 \mathrm{gm} \%$. The findings of routine peripheral blood films were noted and tabulated. The tabulations regarding the age, parity, inter-pregnancy spacing, and type of pregnancy were also done, and the data analyzed by various tabulations, bar diagrams, pie-charts and calculation of percentages. The prevalence of iron deficiency versus non-iron deficiency anemia was also noted.

\section{RESULTS}

The present study revealed that anemia as an isolated morbidity in pregnant females is very common. It was found to be common in age group of 30-35 years and those having parity of three. Inter-pregnancy spacing also had an impact on the occurrence on the anemia and was found that less gaps being associated with more incidence of anemia.

The most common type of anemia was iron deficiency anemia which is almost in all cases due to nutritional deficiencies. The mild and moderate cases in the present study were treated by oral iron therapy while noncompliant and severe cases were managed by intravenous iron therapy and if warranted by blood transfusions. The main difficulty in cases where oral iron was prescribed was the compliance as oral iron therapy is associated with gastric upset. Despite counselling about side-effects, a lot of difficulty was encountered in ensuring that patients take proper iron therapy. The severity of anemia in our patients has been categorized as mild if $\mathrm{Hb} 10 \mathrm{~g} \%$ to 10.9 $\mathrm{g} \%$, moderate if $\mathrm{Hb} 7 \mathrm{~g} \%$ to $10 \mathrm{~g} \%$ and as severe if $\mathrm{Hb}$ less than $7 \mathrm{~g} \%$ (Table 1).

Table 2: Age-distribution of patients.

\begin{tabular}{|l|l|}
\hline Age group (years) & Number of patients \\
\hline$\leq 20$ & 60 \\
\hline $20-25$ & 75 \\
\hline $25-30$ & 68 \\
\hline $30-35$ & 190 \\
\hline$\geq 35$ & 107 \\
\hline
\end{tabular}

Table 2 describes the number of patients in various age groups. Most of our patients were in age group of 30-35 years of age and 60 patients were less than 20 years of age.

Table 3: Type of pregnancy.

\begin{tabular}{|ll|}
\hline Type & Number of patients \\
\hline Singleton & 445 \\
\hline Multiple & 55 \\
\hline
\end{tabular}

445 were having pregnancy with single feutus while 55 patients were having twins (Table 3).

Table 4: Parity of patients.

\begin{tabular}{|ll|}
\hline Parity & Number of patients \\
\hline 1 & 150 \\
\hline 2 & 100 \\
\hline 3 & 168 \\
\hline$>3$ & 82 \\
\hline
\end{tabular}

Table 4 describes the parity of patients with 150 patients as primigravida while 350 were multigravida.

Table 5: Inter-pregnancy spacing.

\begin{tabular}{|ll|}
\hline $\begin{array}{l}\text { Inter-pregnancy } \\
\text { spacing (in Years) }\end{array}$ & Number of patients \\
\hline$<1$ & 177 \\
\hline $1-2$ & 120 \\
\hline $2-3$ & 170 \\
\hline$>3$ & 33 \\
\hline
\end{tabular}

Inter-pregnancy spacing is described in Table 5, less than 1 year spacing was in 177 patients while in 120 patients it was 1-2 years, 170 patients were having inter-pregnancy spacing of 2-3 years and 33 patients were having more than 3 years of spacing. 232 patients were having associated nausea and vomiting while 268 were not having any such symptoms (Table 6). 
Table 6: Associated nausea and vomiting.

\begin{tabular}{|ll|}
\hline Association with & Number of patients \\
nausea and vomiting & 232 \\
\hline Positive & 268 \\
\hline Negative & \\
\hline
\end{tabular}

Mild anemia was seen in 160 patients while most of the patients (250) were having moderate anemia and severe anemia was detected in 90 patients (Table 7).

Table 7: Severity of anemia.

\begin{tabular}{|ll|}
\hline Degree of anemia & Number of patients \\
\hline Mild (10-10.9 gm\%) & 160 \\
\hline Moderate $(7-10$ gm $\%)$ & 250 \\
\hline Severe $(<7$ gm $\%)$ & 90 \\
\hline
\end{tabular}

On examination of peripheral smears normocytic normochromic RBC's with few microcytes was seen in 115 patients, anisocytes with normocytic normochromic RBC's admixed with hypochromic cells in 65 patients, dimorphic picture with both macrocytes with hypochromic cells and polychromatic cells in 110 patients, normocytic hypochromic picture with microcytes in 150 patients, while hypochromic microcytic picture in 60 patients (Table 8).

Table 8: Peripheral blood picture of anemic patients.

\begin{tabular}{|ll|}
\hline PBF Picture & No. of patients \\
\hline $\begin{array}{l}\text { Normocytic Normochromic RBC's } \\
\text { with few microcytes }\end{array}$ & 115 \\
\hline $\begin{array}{l}\text { Anisocytes with normocytic } \\
\text { normochromic RBC's admixed } \\
\text { with hypochromic cells }\end{array}$ & 65 \\
$\begin{array}{l}\text { Dimorphic picture with both } \\
\text { macrocytes with hypochromic cells } \\
\text { and polychromatic cells }\end{array}$ & 110 \\
\hline $\begin{array}{l}\text { Normocytic hypochromic picture } \\
\text { with microcytes }\end{array}$ & 150 \\
\hline \begin{tabular}{l} 
Hypochromic microcytic picture \\
\hline
\end{tabular} & 60 \\
\hline
\end{tabular}

The outcome of pregnancy and associated complications are described in Table 9.

Table 9: Pregnancy outcome and associated complications.

\begin{tabular}{|ll|}
\hline Parameter & Number of patients \\
\hline Pre-term delivery & 95 \\
\hline Post-term delivery & 20 \\
\hline $\begin{array}{l}\text { Low-birth weight babies } \\
\text { (<2500gms) }\end{array}$ & 90 \\
\hline Antepartum hemorrhage & 10 \\
\hline Post-partum hemorrhage & 20 \\
\hline
\end{tabular}

Pre-term deliveries were in 95 while post term deliveries were seen in 20 patients. Ante-partum hemorrhage and post-partum hemorrhage was seen in 10 and 20 patients respectively. 90 patients were low-birth weight babies (2500 gm).

Table 10: Mode of delivery.

\begin{tabular}{|ll|}
\hline Mode & Number of patients \\
\hline $\begin{array}{l}\text { Normal Vaginal delivery with } \\
\text { Medio-lateral episiotomy }\end{array}$ & 385 \\
\hline $\begin{array}{l}\text { Normal Vaginal delivery } \\
\text { without Medio-lateral } \\
\text { episiotomy }\end{array}$ & 35 \\
\hline $\begin{array}{l}\text { Lower-segment caesarean } \\
\text { section }\end{array}$ & 80 \\
\hline
\end{tabular}

Table 10 describes the mode of deliveries; lower segment caesarean section was done in 80 patients while normal deliveries were conducted in 420 patients.

Table 11: Type of anemia based on ferritin levels and PBF picture.

\begin{tabular}{|ll|}
\hline Type of anemia & Number of patients \\
\hline $\begin{array}{l}\text { Iron-deficiency anemia } \\
\text { (Nutritional deficiency) }\end{array}$ & 325 \\
\hline Non-iron deficiency anemia & 175 \\
\hline
\end{tabular}

Iron deficiency anemia was detected in 325 and non-iron deficiency anemia in 175 patients (Table 11).

\section{DISCUSSION}

In India, anemia is the second most common cause of maternal deaths accounting for $20 \%$ total maternal deaths second only to hemorrhage associated with pregnancy $(\mathrm{APH} / \mathrm{PPH}){ }^{3}$

The WHO defines anemia in pregnancy as hemoglobin less than $11 \mathrm{gm} \%$. The degree of anemia is graded according to hemoglobin concentration. ${ }^{4}$

Expansion of plasma volume and utilization by the fetus of substrates needed for the building of the hemoglobin molecules will accentuate any pre-existing anemia. Females who are mildly anemic before pregnancy will become markedly anemic and patients with severe anemia will become symptomatic by second trimester. ${ }^{5}$

Reasons for increased incidence of anemia in pregnancy include increased demand by the growing fetus, decreased intake due to poor appetite and vomiting of pregnancy, faulty dietary habits, pre-pregnancy anemia, decreased inter-pregnancy interval, worm infestation, and poor availability of iron in food stuffs. ${ }^{1}$

Anemia is one of the most commonly encountered morbidity in general population especially in pregnant females. The incidence is higher in developing countries due to abnormal dietary habits and various food fads practiced by various societies during the pregnancy. 
Anemia has adverse impact on maternal as well as child health. A number of programs have been started by the Governments of different countries to tackle this issue. Recently iron fortified foods have been approved by the food regulatory authorities of many countries. ${ }^{6}$

The screening of pregnant females for anemia is as important as screening for pregnancy induced hypertension or gestational diabetes mellitus. It gives the basic idea regarding the prevalence of anemia and its types in the society. It also reflects the effect of various supplementation programmes. ${ }^{7}$

In a study by Agarwal et al, it was found that $84 \%$ pregnant females were anemic. ${ }^{8}$ Present study was focused on the patients who had anemia without any other comorbidity. The present study revealed that iron deficiency anemia is still the most common entity among the pregnant females $(65 \%)$.

Al-Farsi YM et al found out that increase in parity increases the risk of anemia-in-pregnancy in a doseresponse fashion. ${ }^{9}$ The present study also proved that the higher the parity, higher the incidence of anemia-inpregnancy.

Anemia is associated with maternal as well as fetal morbidity in terms of pre-term delivery, low-birth weight babies. The present study found that the most common complications associated with anemia-in-pregnancy were pre-term delivery on maternal side and low-birth weight babies on fetal side. The least associated complications included antepartum and post-partum hemorrhage.

Gautam VP et al stated that in pregnant females, the prevalence of severe anemia was higher in age $>25$ years. ${ }^{10}$ In the present study, the severe anemia was found in only $18 \%$ of cases most of which were aged $>30$ years.

Iron deficiency anemia is still the most common cause of anemia in pregnant females. The common causes in the study population relate to the dietary deficiency. The factors contributing to the dietary deficiency include abnormal food habits, worm infestations, less iron intake, and non-compliance with the oral iron therapy. The iron deficiency anemia is treated by oral iron therapy in mild and moderate cases. The severe cases are treated by intravenous iron infusions and if needed blood transfusions. ${ }^{11}$ In the present study, the same principle was applied for management of anemia.

The peripheral blood picture plays an important role in the evaluation of the anemia-in-pregnancy as it helps to differentiate between iron and non-iron deficiency anemia. $^{12,13}$

The antenatal period in anemic patients is similar in terms of pregnancy outcome and mode of delivery to the nonanemic women but care is needed in postpartum period in anemic patients and incidence of postpartum hemorrhage is high in anemic women as compare to non-anemic women. ${ }^{14}$ The same trend was seen in the present study.

In the present study, the non-iron deficiency anemia was due to folic-acid and cobalamin deficiencies in most of the cases and idiopathic in few cases. The same cases were treated by the folic acid and cobalamin supplementation.

\section{CONCLUSION}

The present study concludes that anemia is still rampant in the society especially in pregnant women. The main cause of anemia-in-pregnancy is still the iron deficiency anemia. The peripheral blood picture, hemoglobin estimation, and serum ferritin levels form the basic pillars in the evaluation of the etiology and type of anemia. The multiple government sponsored facilities are to be made available to each pregnant female and that requires community, government as well as healthcare professional's participation.

\section{Funding: No funding sources}

Conflict of interest: None declared

Ethical approval: The study was approved by the Institutional Ethics Committee

\section{REFERENCES}

1. Kaul RR, Ahmad J, Baba T, Shoib S, Ahmad A, Ashraf M, et al. Anemia in pregnant women in a rural block of Kashmir valley: Its prevalence and socio-demographic associates. Int J Med Sci Pub Health. 2013:2(4);814-8.

2. Goonewardene M, Shehata M, Hamad A. Anaemia in pregnancy. Best Pract Res Clin Obstet Gynaecol. 2012;26(1):3-24.

3. Montgomery AL, Ram U, Kumar R, Jha P, Million Death Study Collaborators. Maternal mortality in India: causes and healthcare service use based on a nationally representative survey. PloS One. 2014;9(1):e83331.

4. Sharma JB, Shankar M. Anemia in Pregnancy. JIMSA. 2010;23(4):253-60.

5. Wright S, Earland D, Sakhuja S, Junkins A, Franklin $\mathrm{S}$, Padilla L, et al. Anemia in pregnancy in Western Jamaica. Int J Women's Health. 2017;9:431-9.

6. Huma N, Salim-Ur-Rehman, Anjum FM, Murtaza MA, Sheikh MA. Food fortification strategy-preventing iron deficiency anemia: a review. Crit Rev Food Sci Nutr. 2007;47(3):259-65.

7. Raghuram V, Anil M, Jayaram S. Prevalence of anemia amongst women in the reproductive age group in a rural area in south India. Int $\mathrm{J}$ Bio Med Res. 2012;3(2):1482-4.

8. Agarwal KN, Agarwal DK, Sharma A, Sharma K, Prasad K, Kalita MC, et al. Prevalence of anemia in pregnant and lactating women in India. Indian J Med Res, 2006;124:173-84. 
9. Al-Farsi YM, Brooks DR, Werler MM, Cabral HJ, Al-Shafei MA, Wallenburg HC. Effect of high parity on occurrence of anemia in pregnancy: a cohort study. BMC Pregnancy and Childbirth. 2011;11:1-7.

10. Gautam VP, Bansal Y, Taneja DK, Saha R. Prevalence of anemia amongst pregnant women and its socio-demographic associates in a rural area of Delhi. Indian J Comm Med. 2002;27:4-12.

11. Khalafallah AA, Dennis AE. Iron deficiency anaemia in pregnancy and postpartum: pathophysiology and effect of oral versus intravenous iron therapy. J Pregnancy. 2012;2012:630519.

12. Greenberg JA, Bell SJ, Guan Y, Yu Y. Folic acid supplementation and pregnancy: more than just neural tube defect prevention. Rev Obstet Gynecol. 2011;4(2):52-9.
13. Kumar P, Jindal G, Guglani V. A case of anemia: How important is peripheral blood film before transfusing? Asian J Transfusion Sci. 2017;11(1):756.

14. Sehgal R, Kriplani A, Vanamail P, Maiti L, Kandpal $\mathrm{S}$, Kumar N. Assessment and comparison of pregnancy outcome among anemic and non-anemic primigravida mothers. Indian $\mathrm{J}$ Public Health. 2016;60(3):188-94.

Cite this article as: Ara S, Saldanha CL, Khan I. Anemia in antenatal patients and its outcome: an experience in tertiary care centre. Int J Reprod Contracept Obstet Gynecol 2018;7:3263-7. 